\title{
KEBIJAKAN JAMINAN SOSIAL TENAGA KERJA SEKTOR INFORMAL BERBASIS KEADILAN SOSIAL UNTUK MENINGKATKAN KESEJAHTERAAN
}

\author{
Siti Ummu Adillah ${ }^{\mathrm{a}}$ dan Sri Anik ${ }^{\mathrm{b}}$ \\ ${ }^{\mathrm{a}}$ Fakultas Hukum Universitas Sultan Agung Semarang; ${ }^{\mathrm{b}}$ Fakultas Ekonomi Universitas Sultan \\ Agung Semarang \\ e-mail: ummu@unissula.ac.id; srianieks@yahoo.co.id
}

\begin{abstract}
s
The implementation of social security programs for informal sector workers is a priority for labor outside the employment relationship is dominated workforce in Indonesia. Implementation of this program, there are still barriers include: lack of cooperation between the Social Security Agency (BPJS) Employment in the informal sector workforce, lack of socialization, difficult to contact and trace the existence of self-employment, while on the side of labor, namely payment of dues and the amount of the payment of compensation that do not correspond to the level of workplace accidents.
\end{abstract}

Keywords : Policy, the Social Security Employment Agency, informal sector

\begin{abstract}
Abstrak
Penyelenggaraan program jaminan sosial bagi tenaga sektor informal menjadi prioritas karena tenaga kerja diluar hubungan kerja ini mendominasi angkatan kerja di Indonesia. Pelaksanaan program ini masih terdapat hambatan-hambatan antara lain: kurangnya kerjasama antara Badan Penyelenggara Jaminan Sosial (BPJS) Ketenagakerjaan dengan pihak tenaga kerja sektor informal, kurangnya sosialisasi, sulitnya menghubungi dan menelusuri keberadaan tenaga kerja mandiri, sedangkan dari sisi tenaga kerja yaitu pembayaran iuran dan jumlah pembayaran santunan yang tidak sesuai dengan tingkat kecelakaan kerja.
\end{abstract}

Kata Kunci: Kebijakan, Jaminan Sosial Tenaga Kerja, Sektor Informal

\section{A. Pendahuluan}

Pemerintah sejak 1 Januari 2014 mewujudkan amanah Pasal 34 UUD NRI Tahun 1945 yakni dengan melaksanakan Sistem Jaminan Sosial Nasional (SJSN). Badan Penyelenggara Jaminan Sosial (BPJS) Ketenagakerjaan memberikan perlindungan bagi tenaga kerja untuk mengatasi risiko tertentu dan penyelenggaraannya menggunakan mekanisme asuransi sosial. Sebagai Badan Usaha Milik Negara yang bergerak dalam bidang asuransi sosial BPJS Ketenagakerjaan dahulu bernama PT Jamsostek (Persero) merupakan pelaksana UndangUndang Jaminan Sosial Tenga Kerja. Sesuai UU Nomor 40 Tahun 2004 tentang Sistem Jaminan Sosial Nasional (SJSN) dan UU Nomor 24 Tahun 2011 tentang Badan Penyelenggara Jaminan Sosial (BPJS), BPJS Ketenagakerjaan merupakan badan hukum nirlaba. Menjadi peserta BPJS Ketenagakerjaan tidak hanya wajib bagi tenaga kerja di sektor formal, namun juga tenaga kerja informal. Angkatan kerja di Indonesia saat ini mencapai 110 
juta orang dengan rincian sektor informal sebanyak 70 juta orang dan 40 juta orang sektor formal. Setelah PT Jamsostek bertransformasi menjadi BPJS Ketenagakerjaan, maka semua pekerja akan terlindungi. Namun, dapat dibayangkan kesulitan yang akan dihadapi kalau pekerja sektor informal yang jumlahnya 70 juta dan tersebar diseluruh pelosok Indonesia harus membayar iuran Jaminan Sosial Tenaga Kerja.

Pasal 28 H Undang-Undang Dasar Negara Republik Indonesia Tahun 1945 menekankan bahwa tenaga kerja berhak atas jaminan sosial tenaga kerja yang memungkinkan pengembangan dirinya secara utuh sebagai manusia yang bermartabat. UU Nomor 3 Tahun 1992 tentang Jaminan Sosial Tenaga Kerja menekankan bahwa “Tenaga kerja adalah setiap orang yang mampu melakukan pekerjaan baik di dalam maupun di luar hubungan kerja, guna menghasilkan barang atau jasa untuk memenuhi kebutuhan masyarakat”. Namun hingga saat ini UU Nomor 3 Tahun 1992 tersebut baru efektif bagi tenaga kerja yang berkerja di dalam hubungan kerja, sedangkan pekerja informal dengan jumlah yang lebih besar belum terlindungi. Apabila suatu pemerintahan mencanangkan untuk melaksanakan suatu sistem jaminan sosial, sebenarnya pemerintah tersebut berjanji kepada para pekerja dan anggota keluarganya akan masa depan kesejahteraan mereka. Bila janji tersebut gagal dipenuhi maka kredibilitas pemerintah yang telah dibangun dengan susah payah akan sulit dipulihkan.

Pengalaman negara lain dalam mengelola program jaminan sosialnya seringkali menunjukkan bahwa pemerintahan berikutnya biasanya gagal dalam memenuhi janjinya yang disebabkan karena perhitungan yang tidak tepat. Ketidaktepatan perhitungan biasanya karena terlalu tingginya perkiraan (over estimate) akan pemasukan dan rendahnya perkiraan (under estimate) akan biaya yang harus ditanggung dari program tersebut. Dengan demikian perencanaan dalam pengembangan SJSN merupakan sesuatu yang sangat seriusdan harus dipikirkan secara matang dengan menyerap masukan dari semua pihak serta didasarkan pada ekspektasi yang realistis.

Jaminan sosial adalah suatu kebijakan publik dengan demikian harus jelas tujuan yang ingin dicapai. Apakah tujuannya mendorong agar pekerja formal menabung bagi hari tuanya? Apakah tujuannya agar pekerja formal mengasuransikan dirinya terhadap penyakit berat dan kecelakaan? Apakah sistem Jamsosnas yang akan kita laksanakan direncanakan untuk memiliki unsur pemerataan? Apakah tujuannya untuk juga melindungi pekerja informal? Untuk memenuhi tujuan yang berbeda tersebut diperlukan berbagai kebijakan dan program 
yang berbeda pula. Misalnya, program Jamsosnas yang mengharuskan peserta untuk mengiur sangat tidaklah tepat bagi pekerja informal. Pekerja informal di Indonesia jumlahnya sangat besar (sekitar 70\% dari angkatan kerja) dan sangat tersebar diseluruh pelosok perdesaan sampai perkotaan. Biaya untuk memungut iuran ini akan sangat mahal dan tidak sebanding dengan jumlah iuran yang dapat dikumpulkan. Dengan kata lain kuranglah tepat kalau program Jamsosnas akan dibangun hanya menggunakan satu pilar untuk mencakup semua jenis manfaat dan mencakup seluruh lapisan masyarakat. Program Jamsosnas harus dibangun melalui beberapa pilar. Bagi masyarakat miskin program Jamsosnas akan lebih baik diselenggarakan melalui program tersendiri yang dibiayai oleh dana pemerintah.

Isu good governance dalam pelaksanaan Jamsosnas perlu mendapat perhatian terutama di negara yang birokrasinya terkenal sarat dengan Korupsi, Kolusi, dan Nepotisme (KKN). Program yang sudah ada seperti Jamsostek mempunyai angka tunggakan iuran yang tinggi, nilai pengembalian investasi yang rendah, serta manfaat yang rendah pula. Dari potensi peserta Jamsostek yaitu 22 juta pekerja formal, hanya sekitar 9 juta yang benar-benar secara teratur membayar iuran tiap bulannya. Dilihat dari pendapatannya maka pekerja kita baik di desa dan di kota yang berstatus kepala rumah tangga masih didominasi oleh mereka yang berpendapatan antara 600-800 ribu rupiah perbulannya. Mereka yang berstatus kepala rumah tangga yang berpendapatan di atas 1 juta rupiah perbulan hanyalah sekitar 4,5 juta orang. Masih banyak pekerja yang memperoleh upah di bawah upah minimum. Keadaan pasar tenaga kerja juga masih belum menggembirakan. Sebagian besar dari pekerja kita di sektor formal adalah pekerja yang kurang terampil (sekitar 50 \% adalah lulusan SD). Dengan demikian bila sampai mereka di PHK dari pekerjaan formal maka dapat terbayangkan akan sangat lama bagi mereka untuk memperoleh pekerjaan formal lagi. Apabila iuran yang nantinya akan dipungut untuk membiayai program Jamsosnas dirasakan sangat berat baik oleh pekerja maupuan pemberi kerja maka kemungkinan menciutnya lapangan pekerja formal tidak dapat dihindari.

Secara garis besar, jaminan sosial dapat dibagi menjadi dua bagian yaitu yang bersifat jangka panjang seperti jaminan hari tua, pensiun, sementara putus kerja, dan kematian serta jaminan yang bersifat jangka pendek seperti jaminan kesehatan dan kecelakaan diri. Pendanaan jaminan sosial berbentuk asuransi sosial dapat dipaksakan kepada setiap penduduk atau pemberi kerja. Pemaksaan pembayaran iuran, seperti halnya pembayaran 
pajak, dilakukan karena mekanisme pasar (tidak ada pemaksaan) gagal memenuhi tujuan jaminan sosial. Asuransi komersial hanya bisa memberikan jaminan kepada yang mau dan mampu membeli saja (Joni Emirzon, 2005: 9). Penelitian ini akan memperkaya khasanah pengembangan ilmu hukum khususnya bidang jaminan sosial (asuransi sosial) bagi tenaga kerja sektor informal. Fokus penelitian ini pada kebijakan pemerintah yang efektif berbasis nilai keadilan sosial untuk mewujudkan Jamsostek bagi pekerja sektor informal.Dengan politik hukum yang tepat diharapkan dapat mengoptimalkan penerimaan pemerintah guna mewujudkan SJSN dan fungsi menyejahterakan rakyat oleh negara (Welfare State) serta mengurangi angka kemiskinan dimana pekerja sektor informal tercakup didalamnya.

Penelitian ini terkait dengan nasib sebagian besar rakyat yang bekerja di sektor informal dan belum tercakup dalam program jaminan sosial. Sampai saat ini belum tergambar secara jelas adanya kajian dan analisa mengenai besarnya iuran, siapa yang akan menanggung, serta bagaimana manajemen keuangan akan dilaksanakan baik untuk jangka pendek maupun jangka panjang. Berdasarkan uraian di atas maka permasalahan dapat dirumuskan bagaimanakah kebijakan jaminan sosial ketenagakerjaan sektor informal yang berbasis keadilan dan dapat meningkatkan kesejahteraan rakyat?

\section{B. Metode Penelitian}

Penelitian ini bersifat analisis deskriptif dengan menggunakan pendekatan kebijakan (policy approach). Pendekatan analisis kebijakan mengkaji tentang aspek filosofis, sosiologis dan yuridis dari politik hukum pengelolaan jaminan sosial ketenagakerjaan. Masing-masing pendekatan pada aspek-aspek tersebut akan digunakan pada tingkat kedalaman penelitian yang berbeda. Adapun metode dan teknik penelitian yang digunakan adalah gabungan antara studi literatur dan observasi lapangan dengan wawancara terstruktur, dan wawancara mendalam (indepth interview). Data dikumpulkan melalui beberapa cara yaitu wawancara menggunakan kuesioner tertutup yang disampaikan kepada pelaku usaha sektor informal di Kota Semarang. Pemilihan responden dilakukan dengan cara accident sampling (yang ditemui). Pengambilan data dengan cara ini dimaksudkan untuk mengetahui karakteristik, aspirasi para pekerja sektor informal menyangkut jaminan sosial melalui BPJS Ketenagakerjaan.

Wawancara melalui kuesioner terbuka disampaikan kepada tokoh kunci yang memahami masalah jaminan sosial ketenagakerjaan khususnya sektor informal. Berbeda dengan 
kuesioner tertutup, wawancara ini dilakukan untuk menggali permasalahan secara lebih mendalam guna menemukan permasalahan yang paling mendasar diantara permasalahan lainnya. Pengambilan data ini juga dimaksudkan untuk mengetahui alternatif solusi bagi kebijakan jaminan sosial ketenagakerjaan sektor informal yang berbasis nilai keadilan berdasarkan Pancasila.

\section{Hasil Penelitian dan Pembahasan}

Isu strategis yang diteliti adalah masalah kemiskinan yang bersifat struktural (Kebijakan pemerintah dan perundang-undangan), dengan kajian aspek ekonomi, kelembagaan, dan peraturan perundangan untuk mendukung kebijakan makro pemerintah dalam pengentasan kemiskinan melalui skema jaminan sosial ketenagakerjaan.

Fungsi negara dalam bidang ekonomi, menurut W. Friedman yaitu sebagai penjamin (provider) kesejahteraan rakyat, negara sebagai pengatur (regulator), negara sebagai pengusaha (entrepreneur) atau menjalankan sektor-sektor tertentu melalui Badan Usaha Milik Negara (BUMN), dan negara sebagai wasit (umpire) untuk merumuskan standarstandar yang adil mengenai sektor ekonomi termasuk perusahaan negara (state corporation) (Wolfgang Friedmann, 1971: 3)

Pembangunan nasional merupakan proses perubahan struktural yang dilakukan secara terus menerus dan berkesinambungan. Pembangunan adalah proses natural untuk mewujudkan cita-cita bernegara, yaitu masyarakat makmur sejahtera, adil, dan merata. Proses natural tersebut dapat terlaksana jika asumsi-asumsi pembangunan dapat dipenuhi, yaitu kesempatan kerja atau partisipasi termanfaatkan secara penuh (full employment), setiap orang memiliki kemampuan yang sama (equal productivity, equal access, level playing field), dan masing-masing pelaku bertindak rasional (efficient) (Gunawan Sumodiningrat, 2001: 3).

Michel Todaro berpendapat, pembangunan adalah proses multidimiensional yang melibatkan perubahan-perubahan mendasar dalam struktur sosial, perilaku sosial, dan institusi nasional. Di samping itu, akselerasi pertumbuhan ekonomi, pengurangan ketidakmerataan, dan pemberantasan kemiskinan juga diagendakan (Michael Todaro,1994).

Kemiskinan merupakan masalah kronis yang melanda bangsa Indonesia. Berdasarkan laporan Microcredit Summit tahun 2002, jumlah penduduk dunia yang hidup di bawah garis kemiskinan diperkirakan sekitar 235 juta keluarga, sebagian diantaranya yaitu 157,8 juta 
(67\%) ada di negara-negara Asia. Salah satu upaya penanggulangan kemiskinan adalah dengan memutus mata rantai kemiskinan melalui pemberdayaan kelompok masyarakat yang memiliki usaha pada sektor paling kecil (UKM) dan sektor informal (Euis Amalia, 2009: 2).

\section{Dasar Hukum Badan Penyelenggara Jaminan Sosial bagi Tenaga Kerja yang Melakukan Pekerjaan Diluar Hubungan Kerja}

Dasar hukum penyelenggaraan program jaminan sosial ketenagakerjaan bagi tenaga kerja yang melakukan pekerjaan di luar hubungan kerja mempunyai beberapa dasar hukum yang dapat dijadikan pedoman yaitu:

a. Undang-Undang Nomor 24 Tahun 2011 tentang Badan Penyelenggara Jaminan Sosial

Sistem Jaminan Sosial Tenaga Kerja Nasional merupakan program negara yang bertujuan memberikan kepastian perlindungan dan kesejahteraan sosial bagi seluruh rakyat. Untuk mewujudkan tujuan tersebut maka perlu dibentuk Badan Penyelenggara yang berbentuk badan hukum berdasarkan prinsip kegotongroyongan, nirlaba, keterbukaan, kehati-hatian, akuntabilitas, portabilitas, kepesertaan bersifat wajib, dana amanat, dan hasil pengelolaan dana jaminan sosial tenaga kerja seluruhnya untuk pengembangan program dan untuk sebesar-besar kepentingan peserta.

Badan Penyelenggara Jaminan Sosial (BPJS) Ketenagakerjaan berfungsi menyelenggarakan program jaminan kecelakaan kerja, program jaminan kematian, program jaminan pensiun, dan jaminan hari tua.

BPJS Ketenagakerjaan sebagaimana diatur dalam Pasal 9 bertugas untuk:

1) melakukan dan/atau menerima pendaftaran peserta;

2) memungut dan mengumpulkan iuran dari peserta dan pemberi kerja;

3) menerima bantuan iuran dari pemerintah;

4) mengelola dana jaminan sosial tenaga kerja untuk kepentingan peserta;

5) mengumpulkan dan mengelola data peserta program jaminan sosial tenaga kerja;

6) membayarkan manfaat dan/atau membiayai pelayanan kesehatan sesuai dengan ketentuan program jaminan sosial tenaga kerja; dan

7) memberikan informasi mengenai penyelenggaraan program jaminan sosial tenaga kerja kepada peserta dan masyarakat. 
b. Peraturan Menteri Tenaga Kerja dan Transmigrasi Republik Indonesia Nomor: PER24/MEN/VI/2006 tentang Pedoman Program Jaminan Sosial Tenaga Kerja yang Melakukan Pekerjaan di Luar Hubungan Kerja

Tenaga kerja yang melakukan pekerjaan di luar hubungan kerja, memungkinkan mengalami kecelakaan, sakit, hamil, bersalin, dan meninggal dunia sehingga perlu mendapatkan perlindungan melalui program jamsostek. Tenaga kerja yang melakukan pekerjaan di luar hubungan kerja mempunyai kekhususan tertentu sehingga program perlindungan jamsostek tersebut perlu ditetapkan penyelenggaraan program jamsostek bagi tenaga kerja di luar hubungan kerja dengan peraturan menteri.

\section{Kebijakan Penyelenggaraan Program Jaminan Sosial Tenaga Kerja Sektor Informal} atau Tenaga Kerja Mandiri di Kota Semarang

Pembangunan sektor ketenagakerjaan sebagai bagian dari upaya pembangunan sumber daya manusia merupakan satu bagian yang tidak terpisahkan dengan pembangunan nasional sebagai pengamalan Pancasila dan pelaksanaan Undang-Undang Dasar Tahun 1945. Pembanguan sektor ketenagakerjaan diarahkan pada peningkatan harkat, martabat, dan kemampuan manusia, serta kepercayaan pada diri sendiri dalam rangka mewujudkan masyarakat sejahtera, adil dan makmur baik material maupun spiritual. Dalam pembangunan nasional, peran serta tenaga kerja sektor informal atau tenaga kerja mandiri yaitu tenaga kerja yang melakukan pekerjaan diluar hubungan kerja semakin meningkat dengan disertai berbagai tantangan dan risiko yang dihadapinya. Oleh karena itu kepada tenaga kerja sektor informal tersebut perlu diberikan perlindungan, pemeliharaan dan peningkatan kesejahteraan sehingga pada gilirannya akan meningkatkan produktivitas nasional.

Program jaminan sosial tenaga kerja yang menanggulangi risiko-risiko sekaligus akan menciptakan ketenangan kerja yang pada gilirannya akan membantu meningkatkan produktivitas kerja, jaminan sosial tenaga kerja mendukung kemandirian dan harga diri manusia dalam menghadapi risiko sosial ekonomi. Program jaminan sosial tenaga kerja merupakan perlindungan dasar bagi tenaga kerja dan keluarganya yang memberikan ganti rugi dalam hal ini jika terjadi kecelakaan kerja, jaminan kematian, dan jaminan hari tua. Dengan demikian pada hakikatnya program jaminan sosial tenaga kerja ini memberikan 
kepastian hukum berlangsungnya penerimaan penghasilan keluarga sebagai pengganti sebagian atau seluruh penghasilan yang hilang. Berdasarkan hasil wawancara dengan para kepala bidang yang ada di Kantor Badan Penyelenggara Jaminan Sosial (BPJS) Ketenagakerjaan yakni di Kantor Semarang I dan Semarang II berkaitan dengan keikutsertaan tenaga kerja khususnya dalam program jaminan sosial tenaga kerja sektor informal, sebagai berikut:

a. Setiap tenaga kerja mandiri diwajibkan dalam keikutsertaan program jaminan sosial tenaga kerja untuk memberikan perlindungan sosial ekonomi bagi tenaga kerja di luar hubungan kerja atau tenaga kerja mandiri.

b. Tenaga kerja diluar hubungan kerja atau tenaga kerja mandiri wajib mengikutsertakan dirinya dalam program jaminan sosial tenaga kerja, karena dapat memberikan perlindungan hukum kepada tenaga kerja mandiri atas risiko sosial ekonomi.

c. Tenaga kerja mandiri dalam kepesertaan program jaminan sosial tenaga kerja diwajibkan untuk mengikutsertakan dirinya menjadi peserta jaminan sosial tenaga kerja, karena tenaga kerja memerlukan jaminan sosial tenaga kerja guna menjaga kelangsungan hidupnya dan keluarganya.

Berdasarkan hasil wawancara tersebut dapat diketahui bahwa dalam keikutsertaan program jaminan sosial tenaga kerja, pihak tenaga kerja mandiri merupakan suatu kewajiban. Oleh sebab itu tenaga kerja di luar hubungan kerja wajib ikut serta dalam program kerja jaminan sosial tenaga kerja sehingga mendapat perlindungan hukum dan kepastian hukum guna kelangsungan hidup tenaga kerja dan keluarganya. Keikutsertaan pekerja khususnya sektor informal di Kota Semarang masih belum optimal, sampai saat ini data di kantor BPJS Cabang Semarang II baru sekitar 5.000 pekerja sebagai peserta dari puluhan ribu pekerja sektor informal. Tahun 2015 ini ditargetkan jumlah peserta meningkat sampai dengan 16.000 pekerja (Hasil wawancara dengan Budi Santoso, Kabid Pemasaran BPJS Ketenagakerjaan Cabang Semarang II, 28 Juli 2015).

Sektor Usaha Informal melalui UKM sebagai pelaku ekonomi mayoritas baik pada tingkat nasional, regional maupun lokal memiliki arti penting dan peran strategis dalam menciptakan lapangan pekerjaan, menanggulangi kemiskinan dan mendorong pertumbuhan nilai ekspor non-migas. Akan tetapi UKM masih memiliki beberapa kendala baik secara internal maupun eksternal agar dapat berdaya saing. Adapun kendala internal 
dapat berupa keterbatasan modal, kesulitan bahan baku, rendahnya kapasitas produksi dan kualitas produk, dan lemahnya akses pasar, sedangkan kendala eksternal yang dirasa menghambat perkembangan UKM adalah ancaman produk asing. UKM merupakan salah satu pemecahan bagi pemerintah untuk mengurangi kemiskinan dan pengangguran. Ada sekitar 48 juta UKM yang sedang beroperasi dan bisa menghidupi keluarganya. Banyak pihak menaruh perhatian terhadap UKM ini. Bahkan, negara maju pun memulai usaha dengan UKM (Adler Haymans Manurung, 2008: 9). Berdasarkan data dari Dinas Koperasi dan UMKM Provinsi Jawa Tengah, terdapat 98.465 unit UMKM binaan di Jawa Tengah sampai dengan triwulan III tahun 2014. Terdiri atas 33.772 unit UMKM yang bergerak di bidang produksi/non pertanian, 17.452 unit UMKM pertanian, 35.597 unit UMKM perdagangan, dan 11.644 unit UMKM bidang jasa. Perkembangan jumlah UMKM tahun 2013-2014 sebesar 8.126 unit usaha dengan pertumbuhan mencapai 9,00 $\%$.

Beberapa hambatan dalam kepesertaan pekerja sektor informal di Kota Semarang antara lain:

a. Belum mengetahui adanya program jaminan sosial ketenagakerjaan.

b. Belum menyadari pentingnya ikut serta dalam program jamsostek

c. Besarnya iuran yang harus dibayar setiap bulan

d. SDM petugas BPJS Ketenagakerjaan yang belum memadai

e. Sarana dan prasarana yang belum memadai

Tidaklah mudah untuk membebankan iuran jamsostek pada pekerja sektor informal. Bila terlalu tinggi, masyarakat akan enggan membayar iuran. Namun bila terlalu rendah, maka program jamsosnas tidak akan berjalan karena dana yang kurang. Agar tidak menimbulkan berbagai masalah, maka pemungutan iuran harus memenuhi persyaratan yaitu: pemungutan iuran harus adil, pungutan iuran tidak mengganggu perekonomian, harus efesien, dan sistem pemungutan iuran harus sederhana.

Pengenaan tambahan pungutan yang tinggi cenderung menyebabkan orang berusaha mengelak membayar iuran dan hilangnya lapangan pekerjaan formal. Pekerja yang berupah rendah dan biasanya tidak terampil serta usia muda biasanya akan lebih dahulu menjadi korban hilangnya lapangan kerja formal. Karenanya, perlu dilakukan analisa 
yang mendalam mengenai dampak pengenaan iuran jamsostek terhadap penciptaan kesempatan kerja.

\section{Kebijakan Jaminan Sosial Ketenagakerjaan Berbasis Keadilan untuk Meningkatkan Kesejahteraan}

Kebijakan jaminan sosial ketenagakerjaan berbasis keadilan perlu mempertimbangkan beberapa aspek untuk meningkatkan kesejahteraan rakyat yakni:

a. Perlunya peningkatan sosialisasi/penyuluhan jamsostek khususnya kepada pekerja informal

b. Penertiban terhadap pungutan diluar pajak yang dapat menimbulkan beban berlebihan (tax burden) bagi pekerja

c. Peningkatan jumlah, kemampuan dan kualitas petugas BPJS ketenagakerjaan agar menjadi kompeten dan profesional

d. Peningkatan motivasi dan komitmen BPJS ketenagakerjaan sebagai pengelola dana

e. Pemberian insentif kepada pekerja sektor informal untuk mendorong pertumbuhan usahanya melalui pelatihan-pelatihan, bantuan sarana dan prasarana, modal bergulir dan lain-lain

f. Perlu dilakukan evaluasi dan sinkronisasi Peraturan/SOP untuk disesuaikan dengan perkembangan perekonomian

Faktor-faktor yang berpengaruh terhadap kebijakan Jaminan sosial ketenagakerjaan bagi sektor informal adalah: komitmen pemerintah (BPJS) yang kuat (political will) untuk mendorong pertumbuhan jumlah peserta melalui regulasi yang berbasis keadilan. Pelaku sektor informal perlu ditumbuhkan kesadaran mengikuti jamsostek guna meningkatkan kesejahteraannya. Agar dana hasil pemungutan iuran tersebut dapat dialokasikan untuk mendorong pertumbuhan sektor informal misalnya dalam bentuk pemberian modal, pelatihan, keterampilan, pembinaan yang intensif.

Pada penelitian ini digunakan responden sebanyak 118 Tenaga kerja di sektor informal, yang berada di Kota Semarang, yaitu responden yang mengisi kuisioner dengan benar dan memberikan informasi yang dapat dipertanggungjawabkan.

Tingkat pendidikan responden yang berpendidikan SD/MI berjumlah 41 orang dengan persentase sebesar 34,7\%, SMP/MTs berjumlah 34 orang dengan persentase sebesar 28,8\%, SMA/MA berjumlah 40 orang dengan persentase sebesar 33,9\%, 
Diploma berjumlah 1 orang dengan persentase sebesar 0,8\%, dan Sarjana berjumlah 2 orang dengan persentase sebesar 1,7\%. Berdasarkan tingkat pendidikannya, responden memiliki kemampuan untuk memahami dan menjawab kuesioner dengan baik. Selengkapnya dapat dilihat dalam tabel 3.1.

Tabel 3.1. Tingkat Pendidikan Responden

\begin{tabular}{|c|c|c|c|}
\hline No. & Tingkat Pendidikan Responden & Orang & Persentase (\%) \\
\hline 1. & Sarjana & 2 & 1.7 \\
\hline 2. & D3 Komunikasi & 1 & .8 \\
\hline 3. & SMA/MA & 40 & 33.9 \\
\hline 4. & SMP/MTs & 34 & 28.8 \\
\hline 5. & SD/MI & 41 & 34.7 \\
\hline & Jumlah & 118 & 100.0 \\
\hline & Total & 100 & 100,0 \\
\hline
\end{tabular}

Sumber: Data primer diolah Tahun 2015

Jenis kelamin responden tenaga kerja sektor informal, laki-laki berjumlah 34 orang dengan persentase sebesar 28.8\%, dan responden perempuan berjumlah 84 orang dengan persentase sebesar 71,2\%. Selengkapnya dapat dilihat dalam tabel 3.2

Tabel 3.2. Jenis Kelamin Responden

\begin{tabular}{|c|l|r|r|}
\hline No. & Jenis Kelamin Responden & Orang & \multicolumn{1}{c|}{ Persentase (\%) } \\
\hline 1. & Laki-laki & 34 & 28.8 \\
\hline 2. & Perempuan & 84 & 71.2 \\
\hline \multicolumn{2}{|r|}{} & 118 & 100.0 \\
\hline \multicolumn{2}{|r|}{ Jumlah } & 100 & 100,0 \\
\hline
\end{tabular}

Sumber: Data primer diolah Tahun 2015

Sumber modal usaha responden berasal dari modal sendiri berjumlah 105 orang dengan persentase sebesar 89.0\%. Responden yang mengambil modal dari kredit berjumlah 13 orang dengan persentase sebesar 11.0\%. Responden ambil kredit dari BKK, Perorangan, Bank Titil/Rentenir, BRI, Bank Mandiri, BKM, BNI, berjumlah masingmasing 1 orang dengan persentase sebesar 0,8\%. Responden yang ambil kredit dari BTPN Syari'ah, BPR, dan BANK (tidak Menyebut nama Banknya) masing-masing berjumlah 2 orang dengan persentase sebesar 1.7\%. Selengkapnya dapat dilihat dalam tabel 3.3.

Tabel 3.3. Sumber Modal Usaha Responden

\begin{tabular}{|l|l|r|r|}
\hline No. & \multicolumn{1}{|c|}{ Sumber Modal Usaha Responden } & Orang & Persentase (\%) \\
\hline 1. & Modal Sendiri & 105 & 89.0 \\
\hline
\end{tabular}




\begin{tabular}{|r|l|r|r|}
\hline 2. & Modal Kredit, dari: & \multicolumn{2}{l|}{} \\
\hline & - BKK & 1 & .8 \\
\hline & - Perorangan & 1 & .8 \\
\hline & - Bank Titil/Rentenir & 1 & .8 \\
\hline & - BANK BRI & 1 & .8 \\
\hline & - Bank Mandiri & 1 & .8 \\
\hline & - BKM & 1 & .8 \\
\hline & - BNI & 1 & .8 \\
\hline & - BTPN Syariah & 2 & 1.7 \\
\hline & - BPR & 2 & 1.7 \\
\hline & - BANK (tidak Menyebut nama Banknya) & 2 & 1.7 \\
\hline & Jumlah & 118 & 100.0 \\
\hline & Total & 100 & 100,0 \\
\hline
\end{tabular}

Sumber: Data primer diolah Tahun 2015

Pekerja sektor informal sebagian besar berusia di atas 40 tahun (51\%). Hal ini menunjukkan bahwa mereka yang menggeluti sektor informal kemungkinan besar karena sudah tidak dapat lagi bekerja di sektor formal sebagai karyawan karena faktor usia. Jika dilihat dari lamanya usaha responden, data menunjukkan sebagian besar kurang dari 10 tahun (70,3\%). Hal ini menunjukkan mereka baru merintis usaha sektor informal setelah gagal memasuki sektor pekerja formal baik karena tingkat pendidikan ataupun faktor usia dan kurangnya kompetensi/keahlian yang dimiliki. Selengkapnya dapat dilihat dalam tabel 3.4

Tabel 3.4. Usia Responden

\begin{tabular}{|c|l|r|r|}
\hline No. & Usia Responden & \multicolumn{1}{|c|}{ Orang } & Persentase (\%) \\
\hline 1. & $<20$ tahun & 2 & 1.7 \\
\hline 2. & $20-<30$ tahun & 27 & 22.9 \\
\hline 3. & $30-<40$ tahun & 38 & 32.2 \\
\hline 4. & $>40$ tahun & 51 & 43.2 \\
\hline \multicolumn{2}{r}{ Jumlah } & 118 & 100.0 \\
\hline & Total & 100 & 100,0 \\
\hline
\end{tabular}

Sumber: Data primer diolah Tahun 2015

Kesulitan responden dalam menjalankan usaha karena kesulitan/kekurangan modal berjumlah 74 orang dengan persentase sebesar 62.7\%. Responden yang kesulitan karena Persaingan Usaha/Kesulitan Pemasaran/Banyaknya Pedagang Yang Sama berjumlah 42 orang dengan persentase sebesar 35.6\%. Responden menjawab tidak ada kesulitan 
berjumlah 1 orang dengan persentase sebesar $0.8 \%$. Responden yang menyampaikan lain-lain (kekurangan tenaga), berjumlah 1 orang dengan persentase sebesar 0,8\%. Selengkapnya dapat dilihat dalam tabel 3.5.

Tabel 3.5. Kesulitan Responden Dalam Menjalankan Usaha

\begin{tabular}{|r|l|r|r|}
\hline No. & Kesulitan Responden Dalam Menjalankan Usaha & Orang & Persentase (\%) \\
\hline 1. & Kesulitan/Kekurangan Modal & 74 & 62.7 \\
\hline 2. & $\begin{array}{l}\text { Persaingan Usaha/Kesulitan Pemasaran/Banyaknya } \\
\text { Pedagang Yang Sama }\end{array}$ & 42 & 35.6 \\
\hline 3. & Tidak Ada Kesulitan & 1 & 0.8 \\
\hline 4. & Lain-lain (Kekurangan Tenaga) & 1 & 0.8 \\
\hline \multicolumn{2}{r}{ Jumlah } & 118 & 100.0 \\
\hline \multicolumn{2}{r|}{ Total } & 100 & 100,0 \\
\hline
\end{tabular}

Sumber: Data primer diolah Tahun 2015

Tenaga kerja sektor informal sebagian besar menyatakan bahwa kesulitan dalam menjalankan usaha adalah karena faktor kekurangan modal usaha (62,7\%). Hal ini menunjukan perlunya pemerintah melalui BPJS Ketenagakerjaan untuk dapat membantu sektor informal dengan bantuan modal usaha. Masa depan usaha responden, yang berpendapat masa depan usahanya baik berjumlah 100 orang dengan persentase sebesar 84.7\%. Responden yang berpendapat tidak jelas berjumlah 14 orang dengan persentase sebesar 11.9\%. Responden yang menyampaikan lain-lain (tidak tahu, lumayan, lumayan baik, kurang baik) berjumlah 4 orang dengan persentase sebesar 3,4\%. Selengkapnya dapat dilihat dalam table 3.6.

Tabel 3.6. Masa Depan Usaha Responden

\begin{tabular}{|r|l|r|r|}
\hline No. & \multicolumn{1}{|l|}{ Masa Depan Usaha Responden } & Orang & Persentase (\%) \\
\hline 1 & Baik & 100 & 84.7 \\
\hline 2 & Tidak Jelas & 14 & 11.9 \\
\hline 3 & $\begin{array}{l}\text { Lain-lain (tidak tahu, lumayan, } \\
\text { lumayan baik, kurang baik) }\end{array}$ & 4 & 3.4 \\
\hline \multicolumn{2}{r}{ Jumlah } & 118 & 100.0 \\
\hline Total & 100 & 100,0 \\
\hline
\end{tabular}

Sumber: Data primer diolah Tahun 2015

Tenaga kerja sektor informal menunjukkan optimisme yang tinggi mengenai masa depan usahanya (84,7\%). Hanya ada 11,9\% responden yang merasa pesimistik terhadap 
masa depan usahanya, kelompok inilah yang perlu mendapat pelatihan dan pendampingan dari BPJS Ketenagakerjaan agar usahanya dapat meningkat. Berkaitan dengan jaminan sosial ketenagakerjaan, para responden, yang berpendapat ya, perlu jaminan sosial ketenagakerjaan berjumlah 107 orang dengan persentase sebesar 90.7\%. Responden yang berpendapat tidak perlu berjumlah 11 orang dengan persentase sebesar 9.3\%. Selengkapnya dapat dilihat dalam tabel 3.7.

Tabel 3.7. Perlu Jaminan Sosial Ketenagakerjaan

\begin{tabular}{|c|c|c|c|}
\hline No. & Perlu Jaminan Sosial Ketenagakerjaan & Orang & Persentase (\%) \\
\hline 1 & Ya, Perlu & 107 & 90.7 \\
\hline 2 & Tidak Perlu & 11 & 9.3 \\
\hline & Jumlah & 118 & 100.0 \\
\hline & Total & 100 & 100,0 \\
\hline
\end{tabular}

Sumber: Data primer diolah Tahun 2015

Hampir semua responden (90,7\%) menyatakan perlunya jaminan sosial ketenagakerjaan. Hal ini menunjukkan kesadaran mereka yang tinggi akan jaminan sosial ketenagakerjaan sehingga perlu ditindaklanjuti oleh BPJS Ketenagakerjaan dengan memastikan keikutsertaan mereka pada program Jamsostek khususnya sektor informal. Responden Terhadap Jaminan Sosial Ketenagakerjaan Merupakan Hak Setiap Warga Negara Yang Dilindungi Oleh Undang-Undang, sebagian besar responden, menjawab tahu berjumlah 82 orang dengan persentase sebesar 69.5\%. Responden yang berpendapat tidak tahu berjumlah 36 orang dengan persentase sebesar 30.5\%. Selengkapnya dapat dilihat dalam tabel 3.8.

Tabel 3.8. Responden Terhadap Jaminan Sosial Ketenagakerjaan Merupakan Hak Setiap Warga Negara Yang Dilindungi Oleh Undang-Undang

\begin{tabular}{|r|lr|r|r|}
\hline No. & $\begin{array}{l}\text { Responden Terhadap Jaminan Sosial Ketenagakerjaan } \\
\text { Merupakan Hak Setiap Warga Negara Yang Dilindungi } \\
\text { Oleh Undang-Undang }\end{array}$ & Orang & Persentase (\%) \\
\hline 1 & Tahu & 82 & 69.5 \\
\hline 2 & Tidak Tahu & 36 & 30.5 \\
\hline \multicolumn{2}{r|}{ Jumlah } & 118 & 100.0 \\
\hline & Total & 100 & 100,0 \\
\hline
\end{tabular}

Sumber: Data primer diolah Tahun 2015

Sebagian besar responden (69,5\%) telah mengetahui bahwa Jamsostek merupakan hak setiap warga negara yang dilindungi oleh Undang-undang, namun masih ada 30,5\% 
yang tidak tahu sehingga perlu mendapat sosialisasi dari BPJS Ketenagakerjaan akan hak yang mereka miliki melalui skema SJSN khususnya Jamsostek untuk sektor informal.

Responden Terhadap Adanya BPJS Ketenagakerjaan sebagian besar responden, menjawab tahu berjumlah 74 orang dengan persentase sebesar 62.7\%. Responden yang berpendapat tidak tahu berjumlah 44 orang dengan persentase sebesar 37.3\%. Selengkapnya dapat dilihat dalam tabel 3.9.

Tabel 3.9. Responden Terhadap Adanya BPJS Ketenagakerjaan

\begin{tabular}{|c|l|r|r|}
\hline No. & Responden Terhadap Adanya BPJS Ketenagakerjaan & Orang & \multicolumn{1}{|c|}{ Persentase (\%) } \\
\hline 1 & Tahu & 74 & 62.7 \\
\hline 2 & Tidak Tahu & 44 & 37.3 \\
\hline \multicolumn{2}{|r|}{ Jumlah } & 118 & 100.0 \\
\hline \multicolumn{2}{r|}{ Total } & 100 & 100,0 \\
\hline
\end{tabular}

Sumber: Data primer diolah Tahun 2015

Sebagian besar responden (62,7\%) menyatakan mengetahui keberadaan BPJS Ketenagakerjaan, namun masih ada 37,3\% yang belum tahu adanya BPJS Ketenagakerjaan sehingga perlu mendapatkan sosialisasi. Meskipun sebagian besar responden menyatakan tahu adanya BPJS Ketenagakerjaan namun sebagian besar (50,8\%) menyatakan tidak tahu terhadap program BPJS Ketenagakerjaan, sehingga perlu dilakukan sosialisasi.

Persiapan responden untuk menghadapi risiko kerja, Tidak melakukan apaapa/pasrah karena tidak ada dana berjumlah 50 orang dengan persentase sebesar 42.4\%. Responden yang menjawab menabung sendiri berjumlah 40 orang dengan persentase sebesar 33.9\%. Responden yang Ikut BPJS Ketenagakerjaan (dulu istilahnya JAMSOSTEK) berjumlah 28 orang dengan persentase sebesar 23.7\%. Selengkapnya dapat dilihat dalam tabel 3.10.

Tabel 3.10. Persiapan Responden Untuk Menghadapi Risiko Kerja

\begin{tabular}{|c|l|r|r|}
\hline No. & Persiapan Responden Untuk Menghadapi Risiko Kerja & \multicolumn{1}{|c|}{ Orang } & Persentase (\%) \\
\hline 1 & Tidak melakukan apa-apa/pasrah karena tidak ada dana & 50 & 42.4 \\
\hline 2 & Menabung sendiri & 40 & 33.9 \\
\hline 3 & Ikut BPJS Ketenagakerjaan (dulu istilahnya JAMSOSTEK) & 28 & 23.7 \\
\hline \multicolumn{2}{|r|}{ Jumlah } & 118 & 100.0 \\
\hline
\end{tabular}

Sumber: Data primer diolah Tahun 2015 
Responden yang tidak melakukan apa-apa/pasrah menghadapi resiko kerja sebesar 42,4\% ini menunjukkan perlunya dilakukan sosialisasi oleh BPJS Ketenagakerjaan sehingga mereka menjadi peserta BPJS Ketenagakerjaan. Disamping itu masih ada 33,9\% responden yang juga belum ikut BPJS Ketenagakerjaan meskipun mereka berjaga-jaga dengan upaya menabung sendiri namun perlu diberikan edukasi agar dapat menjadi peserta BPJS Ketenagakerjaan.

Berkaitan dengan pendapat responden tentang pemerintah mengikutsertakan tenaga kerja sektor informal Sebagai peserta Jaminan Sosial Ketenagakerjaan, para responden, yang berpendapat ya, perlu berjumlah 107 orang dengan persentase sebesar 90.7\%. Responden yang berpendapat tidak perlu berjumlah 4 orang dengan persentase sebesar 3.4\%. Responden yang menjawab tidak tahu berjumlah 7 orang dengan persentase sebesar 5.9\%. Selengkapnya dapat dilihat dalam tabel 3.11.

Tabel 3.11. Pendapat Responden Tentang Pemerintah Mengikutsertakan Tenaga kerja sektor informal Sebagai Peserta Jaminan Sosial Ketenagakerjaan

\begin{tabular}{|r|lr|r|r|}
\hline No. & $\begin{array}{l}\text { Pendapat Responden Tentang Pemerintah Mengikutsertakan } \\
\text { Tenaga kerja sektor informal Sebagai Peserta } \\
\text { Jaminan Sosial Ketenagakerjaan }\end{array}$ & Orang & Persentase (\%) \\
\hline 1 & Ya, Perlu & 107 & 90.7 \\
\hline 2 & Tidak Perlu & 4 & 3.4 \\
\hline 3 & Tidak Tahu & 7 & 5.9 \\
\hline \multicolumn{2}{r|}{} & Jumlah & 118 & 100.0 \\
\hline \multicolumn{2}{r|}{ Total } & 100 & 100,0 \\
\hline
\end{tabular}

Sumber: Data primer diolah Tahun 2015

Sebagian besar responden (90,7\%) telah memiliki kesadaran yang tinggi tentang perlunya pemerintah mengikutsertakan sektor informal sebagai peserta jamsostek, hal ini menunjukkan adanya peluang yang besar untuk mengajak mereka menjadi peserta BPJS Ketenagakerjaan.

Alasan responden tentang perlunya pemerintah mengikutsertakan tenaga kerja sektor informal sebagai peserta jaminan sosial ketenagakerjaan menunjukkan kesadaran yang tinggi akan adanya risiko dalam melaksanakan pekerjaan disamping juga hal tersebut merupakan hak setiap warga negara. 
Sebagai tenaga kerja sektor informal, kalau harus membayar iuran jaminan sosial ketenagakerjaan, responden yang menjawab bersdia berjumlah 42 orang dengan persentase sebesar 35.6\%. Responden yang berpendapat keberatan berjumlah 74 orang dengan persentase sebesar 62.7\%. Responden yang menjawab lain-lain berjumlah 2 orang dengan persentase sebesar 1.7\%. Selengkapnya dapat dilihat dalam tabel 3.12

Tabel 3.12. Sebagai Tenaga kerja sektor informal, Kalau Harus Membayar Iuran Jaminan Sosial Ketenagakerjaan

\begin{tabular}{|r|l|r|r|}
\hline No. & $\begin{array}{l}\text { Sebagai Tenaga kerja sektor informal, Kalau Harus } \\
\text { Membayar Iuran Jaminan Sosial Ketenagakerjaan }\end{array}$ & Orang & Persentase (\%) \\
\hline 1 & Bersedia & 42 & 35.6 \\
\hline 2 & Keberatan & 74 & 62.7 \\
\hline 3 & Lian-lain & 2 & 1.7 \\
\hline \multicolumn{2}{r|}{ Jumlah } & 118 & 100.0 \\
\hline & Total & 100 & 100,0 \\
\hline
\end{tabular}

Sumber: Data primer diolah Tahun 2015

Sebagian besar responden (62,7\%) menyatakan keberatan kalau harus membayar iuran jamsostek, hal ini menunjukkan perlunya sosialisasi dan edukasi dari BPJS Ketenagakerjaan tentang mengapa harus membayar iuran dan berapa besarnya serta manfaat yang akan mereka peroleh jika menjadi peserta jamsostek.

Alasan keberatan membayar iuran jaminan sosial ketenagakerjaan, responden yang menjawab karena pendapatan pas-pasan berjumlah 57 orang dengan persentase sebesar 48.3\%. Responden yang berpendapat untuk modal usaha masih kurang berjumlah 17 orang dengan persentase sebesar 14.4\%. Responden yang menjawab Tidak penting ikut JAMSOSNAKER berjumlah 1 orang dengan persentase sebesar $0.8 \%$. Responden yang menjawab Tidak keberatan membayar iuran JAMSOSNAKER berjumlah 43 orang dengan persentase sebesar 36.4\%. Selengkapnya dapat dilihat dalam tabel 3.13.

\section{Tabel 3.13. Alasan Keberatan Membayar Iuran Jaminan Sosial Ketenagakerjaan}

\begin{tabular}{|c|l|r|r|}
\hline No. & $\begin{array}{c}\text { Alasan Keberatan Membayar Iuran Jaminan Sosial } \\
\text { Ketenagakerjaan }\end{array}$ & Orang & Persentase (\%) \\
\hline 1 & Karena pendapatan pas-pasan & 57 & 48.3 \\
\hline 2 & Untuk modal usaha masih kurang & 17 & 14.4 \\
\hline 3 & Tidak penting ikut JAMSOSNAKER & 1 & .8 \\
\hline 4 & Tidak keberatan membayar iuran JAMSOSNAKER & 43 & 36.4 \\
\hline
\end{tabular}


Tabel 3.13. Alasan Keberatan Membayar Iuran Jaminan Sosial Ketenagakerjaan

\begin{tabular}{|c|l|r|r|}
\hline No. & $\begin{array}{c}\text { Alasan Keberatan Membayar Iuran Jaminan Sosial } \\
\text { Ketenagakerjaan }\end{array}$ & Orang & Persentase (\%) \\
\hline 1 & Karena pendapatan pas-pasan & 57 & 48.3 \\
\hline 2 & Untuk modal usaha masih kurang & 17 & 14.4 \\
\hline 3 & Tidak penting ikut JAMSOSNAKER & 1 & .8 \\
\hline 4 & Tidak keberatan membayar iuran JAMSOSNAKER & 43 & 36.4 \\
\hline \multicolumn{2}{r}{ Jumlah } & 118 & 100.0 \\
\hline \multicolumn{2}{r}{ Total } & 100 & 100,0 \\
\hline
\end{tabular}

Sumber: Data primer diolah Tahun 2015

Sebagian besar responden menyatakan keberatan membayar iuran jamsostek dengan alasan karena pendapatan yang pas-pasan (48,3\%) dan untuk modal usaha yang masih kurang (14,4\%), hal ini menunjukkan perlunya pendampingan tentang manajemen keuangan usaha yang baik dari BPJS Ketenagakerjaan sehingga pekerja sektor informal mampu mengelola keuangan dengan tepat.

Sumber dana pemerintah jika memberikan JAMSOSNAKER, responden yang menjawab bersumber dari sumber kekayaan alam Indonesia yang dikelola dengan baik berjumlah 58 orang dengan persentase sebesar $40.2 \%$. Responden yang menjawab dari pajak berjumlah 19 orang dengan persentase sebesar 16.1\%. Responden yang menjawab dari iuran peserta JAMSOSNAKER berjumlah 41 orang dengan persentase sebesar 34.7\%. Selengkapnya dapat dilihat dalam tabel 3.14.

Tabel 3.14. Sumber Dana Pemerintah Jika Memberikan Jamsosnaker

\begin{tabular}{|c|l|r|r|}
\hline No. & Sumber Dana Pemerintah Jika Memberikan Jamsosnaker & \multicolumn{1}{|c|}{ Orang } & Persentase (\%) \\
\hline 1 & Dari sumber kekayaan alam Indonesia yang dikelola dg baik & 58 & 49.2 \\
\hline 2 & Dari Pajak & 19 & 16.1 \\
\hline 3 & Dari iuran peserta JAMSOSNAKER & 41 & 34.7 \\
\hline \multicolumn{2}{|r|}{ Jumlah } & 118 & 100.0 \\
\hline
\end{tabular}

Sumber: Data primer diolah Tahun 2015

Mengenai sumber dana pemerintah sebagian besar responden (49,2\%) menyatakan dari sumber kekayaan alam Indonesia yang dikelola dengan baik sehingga perlu tata kelola pemerintahan yang baik termasuk dari pajak. Disamping itu ada 34,7\% responden yang menyatakan dari iuran peserta jamsostek. 
Agar tenaga kerja sektor informal bersedia dengan senang hati ikut JAMSOSNAKER, responden yang menjawab Perlu adanya sosialisasi dari BPJS Ketenagakerjaan berjumlah 83 orang dengan persentase sebesar 70.3\%. Responden yang menjawab Pengelolaan dana harus baik \& transparan berjumlah 8 orang dengan persentase sebesar 6.8\%. Responden yang menjawab perlu adanya kemudahan mengurus saat mengalami risiko kerja/klaim berjumlah 16 orang dengan persentase sebesar 13.6\%, responden yang menjawab iuran murah/terjangkau berjumlah 10 orang dengan persentase sebesar 8.5\%, responden yang menjawab lain-lain (tidak tahu) berjumlah 1 orang dengan persentase sebesar .8\%. Selengkapnya dapat dilihat dalam tabel 3.15.

Tabel 3.15. Agar tenaga kerja sektor informal bersedia dengan senang hati ikut JAMSOSNAKER.

\begin{tabular}{|r|l|r|r|}
\hline No. & $\begin{array}{c}\text { Agar tenaga kerja sektor informal bersedia dengan } \\
\text { senang hati ikut JAMSOSNAKER }\end{array}$ & Orang & Persentase (\%) \\
\hline 1 & Perlu adanya sosialisasi dari BPJS Ketenagakerjaan & 83 & 70.3 \\
\hline 2 & Pengelolaan dana harus baik dan transparan & 8 & 6.8 \\
\hline 3 & Kemudahan mengurus saat mengalami risiko kerja/klaim & 16 & 13.6 \\
\hline 4 & Iuran murah/terjangkau & 10 & 8.5 \\
\hline 5 & Lain-lain (Tidak Tahu) & 1 & .8 \\
\hline & Jumlah & 118 & 100.0 \\
\hline \multicolumn{2}{r}{ Total } & 100 & 100,0 \\
\hline
\end{tabular}

Sumber: Data primer diolah Tahun 2015

Sebagian besar responden (70,3\%) menyatakan perlu adanya sosialisasi dari BPJS Ketenagakerjaan, dan kemudahan dalam mengurus klaim saat mengalami resiko kerja $(13,6 \%)$, serta iuran yang murah/terjangkau $(8,5 \%)$.

Pendapat responden mengenai jaminan pemerintah dalam meningkatkan kesejahteraan soaial dengan pernyataan bahwa jaminan sosial ketenagakerjaan bagi tenaga kerja sektor informal harus menjadi program kerja utama pemerintah untuk meningkatkan kesejahteraan menunjukan bahwa responden yang menjawab setuju berjumlah 50 orang dengan persentase sebesar 42.4\%. Responden yang menjawab sangat setuju berjumlah 49 orang dengan persentase sebesar 41.5\%. Selengkapnya dapat dilihat pada tabel 3.16.

Tabel 3.16. Jamsosnaker bagi tenaga kerja sektor informal harus menjadi program kerja utama pemerintah untuk meningkatkan kesejahteraan. 


\begin{tabular}{|r|l|r|r|}
\hline No. & $\begin{array}{c}\text { Jamsosnaker bagi tenaga kerja sektor informal harus } \\
\text { menjadi program kerja utama pemerintah untuk } \\
\text { meningkatkan kesejahteraan. }\end{array}$ & Orang & Persentase (\%) \\
\hline 1 & Sangat Tidak Setuju & 6 & 5.1 \\
\hline 2 & Tidak Setuju & 4 & 3.4 \\
\hline 3 & Netral & 9 & 7.6 \\
\hline 4 & Setuju & 50 & 42.4 \\
\hline 5 & Sangat Setuju & 49 & 41.5 \\
\hline \multicolumn{2}{r}{ Jumlah } & 118 & 100.0 \\
\hline \multicolumn{2}{r}{ Total } & 100 & 100,0 \\
\hline
\end{tabular}

Sumber: Data primer diolah Tahun 2015

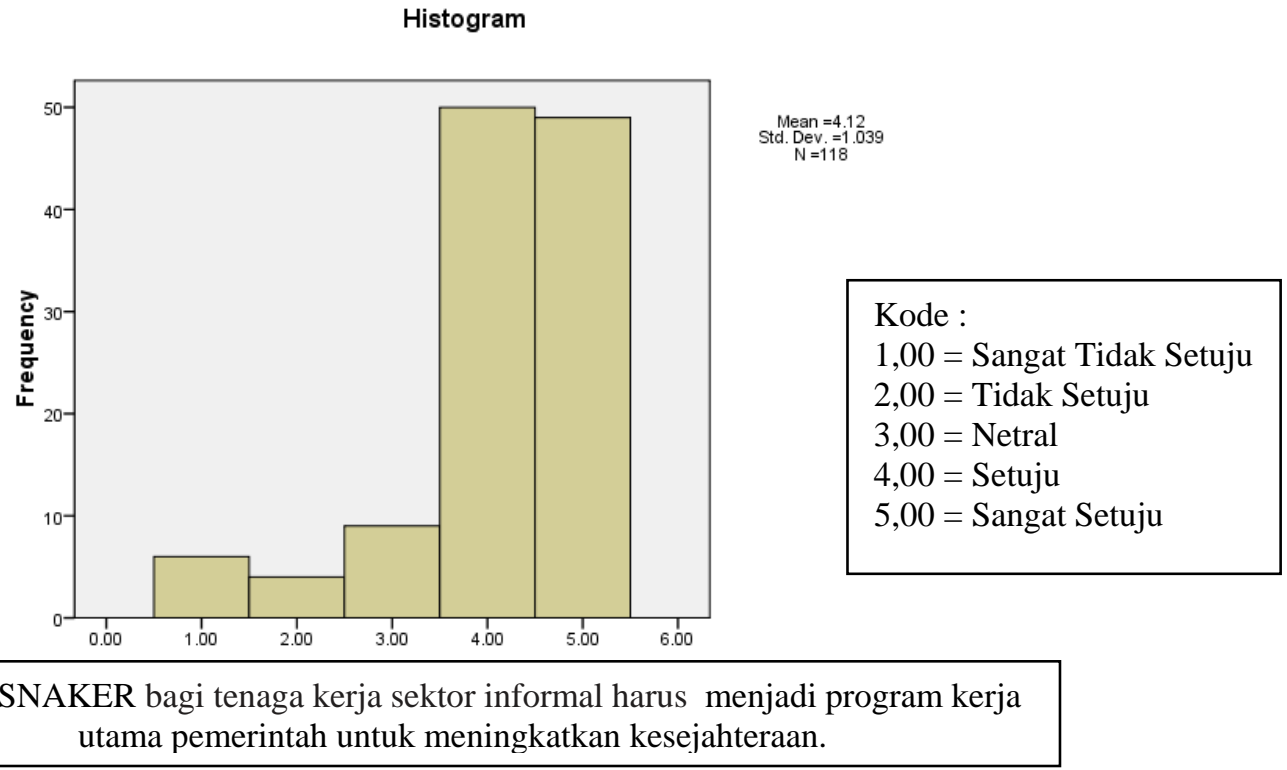

Sebagian besar responden setuju (42,4\%) dan sangat setuju (41,5\%) mengenai jaminan pemerintah dalam meningkatkan kesejahteraan sosial dengan pernyataan bahwa jaminan sosial ketenagakerjaan bagi tenaga kerja sektor informal harus menjadi program kerja utama pemerintah untuk meningkatkan kesejahteraan. Pemerintah harus membuat peraturan yang jelas tentang pengawasan dan pengelolaan dana jaminan nasional ketenagakerjaan berbasis nilai keadilan sosial untuk meningkatkan kesejahteraan.

Penyusunan desain kebijakan jamsostek yang adil dalam upaya meningkatkan kesejahteraan rakyat harus segmentatif disesuaikan dengan tingkat kemampuan pekerja membayar iuran. Perlakuan yang berbeda dari sisi kewajiban dan manfaat yang diperoleh 
pekerja adalah keniscayaan yang merupakan kewajiban sosial negara dan masyarakat secara umum.

Disamping itu, dibutuhkan pula iklim usaha yang mendukung. Iklim Usaha adalah kondisi yang diupayakan Pemerintah Daerah, untuk memberdayakan Usaha Mikro, Kecil, dan Menengah secara sinergis melalui penetapan berbagai peraturan perundang-undangan dan kebijakan di berbagai aspek kehidupan ekonomi agar Usaha Mikro, Kecil, dan Menengah memperoleh pemihakan, kepastian, kesempatan, perlindungan, dan dukungan berusaha yang seluas-luasnya.

\section{Simpulan}

Peran serta tenaga kerja sektor informal atau tenaga kerja mandiri yaitu tenaga kerja yang melakukan pekerjaan diluar hubungan kerja semakin meningkat dengan disertai berbagai tantangan dan risiko yang dihadapinya. Oleh karena itu kepada tenaga kerja sektor informal tersebut perlu diberikan perlindungan, pemeliharaan dan peningkatan kesejahteraan sehingga pada gilirannya akan meningkatkan produktivitas nasional. Program jaminan sosial tenaga kerja yang menanggulangi risiko-risiko sekaligus akan menciptakan ketenangan kerja yang pada gilirannya akan membantu meningkatkan produktivitas kerja, jaminan sosial tenaga kerja mendukung kemandirian dan harga diri manusia dalam menghadapi risiko sosial ekonomi. Program jaminan sosial tenaga kerja merupakan perlindungan dasar bagi tenaga kerja dan keluarganya yang memberikan ganti rugi dalam hal ini jika terjadi kecelakaan kerja, jaminan kematian, dan jaminan hari tua. Dengan demikian pada hakikatnya program jaminan sosial tenaga kerja ini memberikan kepastian hukum berlangsungnya penerimaan penghasilan keluarga sebagai pengganti sebagian atau seluruh penghasilan yang hilang.

Berdasarkan hasil wawancara dengan kepala bidang yang ada di Kantor Badan Penyelenggara Jaminan Sosial (BPJS) Ketenagakerjaan yakni di Kantor Semarang II berkaitan dengan keikutsertaan tenaga kerja khususnya dalam program jaminan sosial tenaga kerja sektor informal, sebabagi berikut:

1. Setiap tenaga kerja mandiri diwajibkan dalam keikutsertaan program jaminan sosial tenaga kerja untuk memberikan perlindungan sosial ekonomi bagi tenaga kerja di luar hubungan kerja atau tenaga kerja mandiri. 
2. Tenaga kerja diluar hubungan kerja atau tenaga kerja mandiri wajib mengikutsertakan dirinya dalam program jaminan sosial tenaga kerja, karena dapat memberikan perlindungan hukum kepada tenaga kerja mandiri atas risiko sosial ekonomi.

3. Tenaga kerja mandiri dalam kepesertaan program jaminan sosial tenaga kerja diwajibkan untuk mengikutsertakan dirinya menjadi peserta jaminan sosial tenaga kerja, karena tenaga kerja memerlukan jaminan sosial tenaga kerja guna menjaga kelangsungan hidupnya dan keluarganya.

4. Keikutsertaan program jaminan sosial tenaga kerja, pihak tenaga kerja mandiri merupakan suatu kewajiban. Oleh sebab itu tenaga kerja di luar hubungan kerja wajib ikut serta dalam program kerja jaminan sosial tenaga kerja sehingga mendapat perlindungan hukum dan kepastian hukum guna kelangsungan hidup tenaga kerja dan keluarganya.

\section{E. Saran}

Perlu diadakan penelitian lanjutan untuk pemetaan peran pemerintah dan stakeholders, sinkronisasi dengan peraturan perundangan lain yang terkait dengan pengelolaan sistem jaminan sosial nasional.

\section{F. Persantunan}

Artikel ini merupakan Publikasi Hibah Penelitian Kompetitif Nasional Penelitian Fundamental yang dibiayai oleh Kementerian Riset, Teknologi dan Pendidikan Tinggi dengan Surat Perjanjian Pelaksanaan Hibah Penelitian Kompetitif Nasional Tahun Pertama Lembaga Penelitian dan Pengabdian Masyarakat (LPPM) Universitas Islam Sultan Agung (UNISSULA) Nomor: 172/B.1/SA-LPPM/IV2015

\section{DAFTAR PUSTAKA}

Adler Haymans Manurung. 2008. Modal untuk Bisnis UKM, Jakarta: Gramedia.

Alex Arifianto. 2004. Reformasi Sistem Jaminan Sosial di Indonesia, Kertas Kerja, Lembaga Penelitian SMERU, Jakarta.

Bappenas. 2004. Menuju Suatu Sistem Jaminan Sosial Yang Dapat Diimplementasikan, Lokakarya Internasional, tanggal 24 Juni, Jakarta.

Benda-Beckmann, Frans von - et all (ed). 1999. Coping with Insecurity: an "Underall" Perspective on Social Security in The Third World, Pustaka Pelajar, Yogyakarta.

Didik J. Rachbini. 1999. “Konsep Jaminan Sosial dan Penerapannya di Indonesia”, Majalah Bisnis dan Ekonomi Politik, Vol. 3 No. 4 Oktober 1999.

Djoned Gunadi M. 2002. "Ketentuan Formal Perpajakan dalam Pemeriksaan Pajak”, dalam Jurnal Perpajakan Indonesia, ISSN 1412-0518, Vol. 1 No. 9, Jakarta 
Ebthisham Ahmad. 1991. "Social Security and The Poor: Choice for Developing Countries", dalam The World Bank Research Observer Vol. 6 No. 1 Januari 1991.

Euis Amalia. 2009. Keadilan Distributif dalam Ekonomi Islam Penguatan Peran LKM dan UKM di Indonesia, Jakarta: RajaGrafindo Persada

Fatorochman. 1996. “Jaminan Sosial dalam Transisi” dalam Populasi, edisi 7(2) Tahun 1996.

Gunawan Sumodiningrat. 2001. “Kepemimpinan dan Pemberdayaan Ekonomi Rakyat”, Naskah Pidato Pidato Pengukuhan Jabatan Guru Besar pada Fakultas Ekonomi Universitas Gadjah Mada 17 Maret 2001, Yogyakarta: UGM

Hasbullah Thabrany. tanpa tahun. Perlu Tekad Baja untuk Jaminan Sosial, makalah Pusat Kajian Ekonomi Kesehatan Universitas Indonesia.

Hunter, T. Wilard. 1968. The Tax Climate for Philanthropy, USA: Garamond/Pridemark Press Inc.

Ingelson, J. 1993. "Mutual Benefit Societies in Indonesia” dalam International Social Security Review, 46(3):69-77.

Joni Emirzon. 2005. Laporan Penelitian Pusat Pengkajian Ekonomi dan Keuangan, Jakarta

Michael Todaro. 1994. Economic Development, Singapore: Longman Singapore Publisher

Moh. Mahfud MD. 2006. Membangun Politik Hukum, Menegakkan Konstitusi, Pustaka LP3ES, Jakarta

Nurhadi. 2007. Mengembangkan Jaminan Sosial Mengentaskan Kemiskinan, Media Wacana, Yogyakarta.

Paul Spicker. 1995. Social Policy: Themes and Approaches, Prentice Hall, London.

Suharto. 2003. Konsepsi dan Strategi Jaminan Sosial, makalah tidak dipublikasikan.

Tb Ace Hasan Syadzily. 2011. “Jaminan Sosial untuk Semua,” Opini Harian Republika, Jakarta 13-5-2011

Tim Crescent. 2003. Menuju Masyarakat Mandiri Pengembangan Model Sistem Keterjaminan Sosial, Gramedia Pustaka Utama, Jakarta.

Yaumil Achir. 2002. “Sistem Jaminan Sosial yang Berkeadilan dan Berkemanusiaan.” Makalah dalam Seminar Nasional Menggalang Masyarakat Indonesia Baru yang Berkemanusiaan Ikatan Sosiologi Indonesia, Bogor, 28-29 Agustus 2002.

Undang-undang Nomor 40 Tahun 2004 tentang Sistem Jaminan Sosial Nasional.

Undang-undang Nomor 24 Tahun 2011 tentang Badan Penyelenggara Jaminan Sosial 